\title{
LOW LEVEL RESISTANCE OF GoOSEgRASS (Eleusine indica) TO Glyphosate in Rio Grande Do Sul-BRAZIL ${ }^{1}$
}

\author{
Resistência de Nivel Baixo de Capim-pé-de-Galinha (Eleusine indica) ao Glyphosate no Rio \\ Grande do Sul
}

VARGAS, L. ${ }^{2}$, ULGUIM, A.R. ${ }^{3}$, AGOSTINETTO, D. ${ }^{4}$, MAGRO, T.D. ${ }^{5}$, and THÜRMER, L. ${ }^{6}$

\begin{abstract}
In the last growing seasons, goosegrass (Eleusine spp.) control failures have been observed following application of glyphosate on Roundup Ready ${ }^{\mathbb{}}$ soybean in Rio Grande do Sul (RS) - Brazil, suggesting this species' resistance to the herbicide. Thus, the objectives of this study were to identify the occurrence of goosegrass resistance to the herbicide glyphosate in RS; and to determine the predominant species of the genus Eleusine, as well as the $\mathrm{LD}_{50}$ and $\mathrm{GR}_{50}$ of the suspected resistant biotypes. Two experiments were conducted under greenhouse conditions: one to identify the biotypes resistant to glyphosate, and the other, a dose-response curve experiment, as well as a study of the botanical characteristics of the species. In the first experiment, 39 biotypes were tested, mainly Eleusine indica, collected with suspected resistance to glyphosate. The glyphosate dose was 2,160 g e.a. ha ${ }^{-1}$, and the control was evaluated at 28 days after treatment. All biotypes were effectively controlled,with the biotypes from the municipality of Boa Vista do Incra showing greater tolerance. Two biotypes suspected of resistance (12.1 and 12.3) and a susceptible biotype in a dose-response experiment were tested at the following doses: 0, 135, 270,540,1,080, 1,620, and 2,160 g e.a. ha-1. The results of this experiment showed that biotype 12.1 does not present resistance to glyphosate and biotype 12.3 has a low level resistance since it is effectively controlled by the herbicide at the maximum dose.
\end{abstract}

Keywords: Glycine max, chemical control, dose-response curve.

RESUMO - Nas últimas estações de cultivo têm-se observado falhas de controle de capim-pé-degalinha (Eleusine spp.), em resposta à aplicação de glyphosate, em lavouras de soja Roundup Ready ${ }^{\circledR}$ no Rio Grande do Sul (RS), sugerindo a resistência da espécie. Diante disso, os objetivos deste trabalho foram identificar a ocorrência da resistência de capim-pé-de-galinha ao herbicida glyphosate no RS, determinar a (s) espécie (s) do gênero Eleusine e determinar a $D L_{50}$ e $G R_{50}$ dos biótipos com suspeita de resistência ao glyphosate. Foram realizados dois experimentos em casa de vegetação, sendo um de identificação de biótipos resistentes ao glyphosate e outro de curva de dose-resposta ao herbicida, além de estudo de caracterização botânica da (s) espécie (s). No experimento de identificação da resistência foram avaliados 39 biótipos, com predominância de Eleusine indica, coletados em áreas com suspeita de resistência ao glyphosate. A dose de glyphosate utilizada foi de $2.160 \mathrm{~g}$ e.a. ha $\mathrm{a}^{-1}$, sendo avaliado o controle aos 28 dias após o tratamento. Todos os biótipos foram eficientemente controlados, porém aqueles oriundos do municipio de Boa Vista do Incra evidenciaram maior tolerância. A partir desse resultado, testaram-se dois biótipos com suspeita de resistência (12.1 e 12.3) e em biótipo suscetivel em experimento de curva de dose-resposta ao glyphosate, sendo as doses de 0, 135, 270, 540, 1.080, 1.620 e $2.160 \mathrm{~g}$ e.a. ha ${ }^{-1}$. Os resultados apontaram que o biótipo 12.1 não apresenta resistência ao glyphosate e o biótipo 12.3 mostra resistência de nivel baixo, sendo eficientemente controlado por glyphosate na dose máxima de registro.

Palavras-chave: Glycine max, controle químico, curva de dose-resposta.

1 Recebido para publicação em 26.6.2012 e aprovado em 27.12.2012.

2 Ph.D., Researcher at Embrapa Trigo, Passo Fundo, RS; Professor at PPGFs/UFPel, <vargas@ cnpt.embrapa.br>; ${ }^{3}$ Agronomist., M.Sc., and Ph.D. student, Postgraduate Program in Plant Health, Universidade Federal de Pelotas - UFPel, <andre_ulguim@yahoo.com.br>; ${ }^{4}$ Professor, Ph.D., UFPel, Agronomy College Eliseu Maciel, Dep. of Plant Health, Campus Universitário, Caixa Postal 354, 96010-900 Capão do Leão-RS, <dirceu.agostinetto@pq.cnpq.br>; ${ }^{5}$ Professor, Ph.D., Universidade de Caxias do Sul - UCS, Campus Universitário de Vacaria - CAMVA, Vacaria-RS, <taisadm@yahoo.com.br>; ${ }^{6}$ Agronomy student at the Agronomy College, UFPel, <lucasthurmer@hotmail.com>.

Planta Daninha, Viçosa-MG, v. 31, n. 3, p. 677-686, 2013 


\section{INTRODUCTION}

Weed management is an important practice in agricultural production systems that seek to raise productivity. In this context, herbicides are an alternative for farmers to keep crops free of competition as well as control these species. However, the exclusive use of this management practice has resulted in an increasing number of resistant weeds.

The use of glyphosate for weed management for over 30 years, intensified with the advent of transgenic crops, has resulted in the emergence of glyphosateresistant weed biotypes. Five of the 13 cases of herbicide-resistant weed species observed in Brazil over the last 10 years were associated with resistance to glyphosate, namely: Conyza bonariensis, Conyza canadensis, Conyza sumatrensis, Digitaria insularis and Lolium multiflorum (Heap, 2012).

Resistance is defined as the inherent and inheritable ability of a biotype, within a given population, to survive and reproduce after exposure to the registered dose of herbicide for control of the species, with adherence to the criteria of application (recommended vegetative stage, weather conditions, among others) (Gazziero et al., 2009). However, control differences are often observed among biotypes at doses below the maximum registered dose of the herbicide. For the purpose of this study, low-level resistance was defined as the one that does not take into consideration the recommended dose of herbicide informed in the package insert, i.e., if there are differences among biotypes at sub-doses, the biotype with low-level resistance to the herbicide is the one to be taken into consideration (Christoffoleti \& López-Ovejero, 2008; Gazziero et al., 2009; Heap, 2010).

Due to control failures of Goosegrass (Eleusine spp.) observed in soybean crops treated with glyphosate, it was suspected that this weed had developed herbicide resistance. There are two species of Goosegrass whose occurrence was described in the state of Rio Grande do Sul: Eleusine indica and E. tristachya (Boldrini et al. 2005). These species differ in their cycle and morphological structures as well as place of occurrence and origin (Boldrini et al. 2005). They are autogamous species with
$\mathrm{C} 4$ photosynthetic cycle, reproduction through seeds and ability to produce up to 40,000 seeds per plant (Kissmann, 2007). Resistance of E. indica to glyphosate was observed in Malaysia, Colombia and the United States. In all those areas, the herbicide had been used consecutively for a long time (Lee \& Ngim, 2000, Mueller et al., 2011; Heap, 2012).

To confirm the occurrence of resistance, the suspected biotypes need to be evaluated. The most appropriate studies involve doseresponse curves, determination of the dose required to promote control of $50 \%$ of the population (LD50) and the dose required to reduce by $50 \%$ the dry matter production of the population (GR50) (Gazziero et al., 2009). Knowledge of these variables yields the resistance factor ( $R F$ ), which refers to the number of times the dose required for controlling the resistant population is greater than the dose that causes the same effect on susceptible populations (Hall et al. 1998).

Therefore, studies are needed to confirm or refute the occurrence of glyphosateresistant populations of Goosegrass, so that the sites of occurrence of resistance can be identified. Knowledge of both this information and the characteristics of the species is important to define future strategies for prevention, control and management of weed resistance to glyphosate.

This study hypothesized that there are biotypes of Goosegrass which belong to the glyphosate-resistant species E. indica and aimed to identify the occurrence of resistance of Goosegrass to glyphosate in the state of Rio Grande do Sul, determine the predominant species of the genus Eleusine and determine LD50 and GR50 values for the suspected resistant biotypes.

\section{MATERIAL AND METHODS}

For this study, visits were made to 24 farms producing soy in eight municipalities of the State of Rio Grande do Sul (RS), in the region called Planalto Central, in 2009. The municipalities were chosen because they were the ones that had the highest production of soybeans observed in RS (IBGE, 2008), as follows: Boa Vista do INCRA, Carazinho, Cruz Alta, Ijuí, Lagoa Vermelha, Passo Fundo, Santa 
Barbara do Sul and Tupanciretã. The plants of Goosegrass which had escaped the control of glyphosate were collected as suspected of having herbicide resistance. Each collection point was georeferenced, and the plants were placed individually for subsequent seed collection and preparation of herbarium specimens used in species identification. Also, two experiments were conducted in a greenhouse in the crop years 2010/11 and $2011 / 12$, and a study was carried out on the botanical identification and characterization of biotypes by morphological analysis of herbarium specimens.

The assay to measure the response of biotypes of Goosegrass to glyphosate was conducted in a randomized complete block design with four replications whose treatment factor consisted of biotypes of different collection sites. The experimental units consisted of $1 \mathrm{~L}$ pots containing sifted Ultisoltype soil. The soil was collected in an area free of the infestation of plants of the genus Eleusine to avoid spontaneous emergence. Fertilizer was applied at a dose of $150 \mathrm{~kg} \mathrm{ha}^{-1}$ with the formula 05-20-20 (NPK), according to soil analysis, as recommended for soybean crops (Comissão..., 2004).

To conduct the experiment, seed dormancy was broken for later planting through mechanical scarification (Dal Magro et al., 2010). Because it is difficult for the species to establish, sowing was held at three dates $(10 / 22,11 / 17$ and 12/04/2010). The first two sowings were held in gerboxes on blotting paper soaked in distilled water, which were placed in BOD-type biological development chambers until germination. Temperature during this period was $25^{\circ} \mathrm{C}$ and the photoperiod was 12/12 h light/dark. After the unfolding of the first leaf, four seedlings were transplanted to each pot (experimental unit), with subsequent thinning to 2 seedlings per pot, and placed in a greenhouse. On the third day, the biotypes were sowed directly in the pots, and thinning was done to adjust the population to 2 plants per pot.

When the plants were at the stage of four leaves per tiller, glyphosate was applied at $2.160 \mathrm{~g}^{2}$.i. ha ${ }^{-1}$. This dose corresponds to the maximum registered dose of the herbicide for desiccation or post-emergent management
(Agrofit, 2010). For this purpose, a $\mathrm{CO}_{2}^{-}$ pressurized backpack sprayer outfitted with flat fan spray nozzles (110.015) was calibrated to provide a flow rate of $150 \mathrm{~L} \mathrm{ha}^{-1}$ of herbicide spray.

Visual control was the variable assessed at 28 days after application of the treatment (DAT), using a percentage scale wherein zero (0) and one hundred (100) corresponded to no injury and death of the plants, respectively (Frans et al. , 1986).

The data were analyzed jointly for normality and homoscedasticity (Shapiro-Wilk and Hartley tests, respectively) and then subjected to analysis of variance $(p \leq 0.05)$. When significance was found, the biotypes were analyzed by comparison of means by Duncan's test $(\mathrm{p} \leq 0.05)$.

The assay of dose-response curve was conducted in a completely randomized design with four replications by sowing three seeds of Goosegrass per pot, with a capacity of $0.5 \mathrm{~L}$ containing Ultisol-type soil sieved with subsequent grinding to achieve the population of 2 plants per pot. Fertilizer was applied two days before sowing, using a dose of $120 \mathrm{~kg} \mathrm{ha}^{-1}$ with formula 5-25-25 (NPK), according to soil analysis and as recommended for soybean (Comissão..., 2004). Prior to seeding, seed dormancy was broken through mechanical scarification (Dal Magro et al., 2010).

Treatments were arranged in a factorial design, whose factor A consisted of the biotypes of Goosegrass 12.1 and 12.3, selected from the previous experiment, from the city of Boa Vista do INCRA, and also a notoriously susceptible biotype, while factor B tested different herbicide doses: $0,6.25,12.5,25,75$, and $100 \%$ of the maximum registered dose of herbicide, which accounted for $0,135,270,540,1,080,1,620$, and $2,160 \mathrm{~g}$ a.i. ha ${ }^{-1}$, respectively.

The treatments were applied at 27 days after sowing (DAS), when plants were at the stage of four leaves per tiller. For this application, a $\mathrm{CO}_{2}$-pressurized backpack sprayer outfitted with 110.015 nozzles was used, providing a flow rate of $150 \mathrm{~L} \mathrm{ha}^{-1}$. The control variables were analyzed at 10, 20 and 30 days after treatment (DAT) and shoot dry mass (DM) at 30 DAT. 
The control assessment was made with a percentage scale, where 0 represented no symptoms and 100 plant death (Frans et al. 1986). To determine DM, the material was collected and dried in a forced air oven at $60{ }^{\circ} \mathrm{C}$ until constant weight and then weighed; the value was transformed into DM per plant.

Later, the values were converted to percentages, and the DM obtained in the treatments with glyphosate was compared with that of the control, considered as $100 \%$.

Data were analyzed for normality (ShapiroWilk test) and homoscedasticity (Hartley's test) and then subjected to analysis of variance $(p \leq 0.05)$. When statistical significance was observed, the analysis was performed by nonlinear sigmoidal logistic regression, with the help of the software SigmaPlot 10.0 (Sigmaplot, 2007), as follows:

$$
y=a /\left[1+\left(x / x_{0}\right)^{b}\right]
$$

where: $y=$ the percentage of control or reduction of $\mathrm{DM} ; x=$ dose of herbicide; $a, x_{0}$ and $b=$ equation parameters, where $a$ is the difference between the maximum and minimum points of the curve, $x_{0}$ is the dose which provides $50 \%$ response of the variable and $b$ is the slope of the curve.

The values for LD50 and GR50 were obtained by calculating the arithmetic value needed to induce $50 \%$ of response according to the parameters generated in the equations of the curves. From the values of LD50 and GR50, the RFs (resistance factors) were obtained for each biotype suspected of resistance, compared to the susceptible one. The use of the RFs required the confidence interval $(\geq 0.95)$ to be checked in the susceptible population, as compared to the others. The overlap of the confidence interval of the susceptible population in relation to the assessed biotype indicates no significant difference between the LD50 or GR50 values of the biotypes (Avila et al., 2005).

\section{RESULTS AND DISCUSSION}

The tests for normality and homoscedasticity indicated that data transformation was not necessary. For the experiment to identify glyphosate-resistant biotypes, there was no statistical significance for the phytotoxicity presented by the biotypes (Table 1). In the assay of dose-response curve, there was interaction among factors for all the variables (Figure 1).

Although there was no difference in the identification experiment, biotype 12.3, collected in the municipality of Boa Vista do INCRA, had a lower numerical value of control over the others, and there was regrowth of some plants (Table 1). The results of this study were similar to those observed by applying glyphosate at the same dose tested $\left(2,160 \mathrm{~g}\right.$ a.i. ha $\left.{ }^{-1}\right)$ on biotypes of Euphorbia heterophylla with suspected herbicide resistance, from $R^{\circledR}$ soybean fields in the state of Rio Grande do Sul (Vargas et al. 2011). For biotypes of Digitaria spp. from soybean fields in Rio Grande do Sul, the application of $1,080 \mathrm{~g}$ a.i. ha ${ }^{-1}$ resulted in efficient control (Fontana, 2011), confirming that the species is resistant to glyphosate.

The fact that failures to control Goosegrass were observed when glyphosate was applyed in $\mathrm{RR}^{\circledR}$ soybean crops in Rio Grande do Sul and also that the result of this study demonstrated control over $95 \%$ over the herbicide treatment indicate that these failures are due to other reasons. Management practices such as use of reduced rates of glyphosate, intensive use of the herbicide and lack of crop rotation have been suggested as causes of control failures of E. heterophylla by this herbicide in Rio Grande do Sul (Vargas et al., 2011). These may also be the reasons for such failure with Goosegrass.

The result observed, under the conditions in which the experiment was conducted, rejects the hypothesis of the occurrence of resistance of Eleusine spp., to glyphosate in $\mathrm{RR}^{\circledR}$ soybean crops in Rio Grande do Sul, but the occurrence of low-level resistance was not discarded. The experiment of dose-response curve, by determining the resistance factor of the selected biotypes, will be able to verify whether or not there is a low level of resistance.

As for determining the species of Goosegrass occurring in Rio Grande do Sul, it was observed that all biotypes belong to the species $E$. indica (Table 1), except for a biotype of E. tristachya, collected in the municipality 
Low level resistance of goosegrass (Eleusine indica) to ...

Table 1 - Control, 28 days after application of 2,160 g a.i. ha-1 of glyphosate, and specification of the species of biotypes of Goosegrass (Eleusine spp.) with suspected resistance, collected in fields of Roundup Ready® soybean crops in the state of Rio Grande do Sul

\begin{tabular}{|c|c|c|c|c|c|}
\hline \multirow{2}{*}{ Town } & \multirow{2}{*}{ Biotype } & \multicolumn{2}{|c|}{ Geographic coordinates } & \multirow{2}{*}{ Species } & \multirow{2}{*}{ Control (\%) } \\
\hline & & Latitude & Longitude & & \\
\hline \multirow{6}{*}{ Lagoa Vermelha } & E 1.1 & -28.223346 & -51.582414 & E. indica (L.) Gaertn. & $100^{\mathrm{ns} 1 /}$ \\
\hline & E 1.2 & -28.223346 & -51.582414 & E. indica (L.) Gaertn. & 100 \\
\hline & E 2.1 & -28.220935 & -51.596618 & E. indica (L.) Gaertn. & 100 \\
\hline & E 2.2 & -28.220935 & -51.596618 & E. indica (L.) Gaertn. & 100 \\
\hline & E 2.3 & -28.220935 & -51.596618 & E. indica (L.) Gaertn. & 100 \\
\hline & E 2.4 & -28.220935 & -51.596618 & E. indica (L.) Gaertn. & 100 \\
\hline \multirow{5}{*}{ Passo Fundo } & E 3.1 & -28.247413 & -52.277758 & E. indica (L.) Gaertn. & 100 \\
\hline & E 3.2 & -28.247413 & -52.277758 & E. indica (L.) Gaertn. & 100 \\
\hline & E 3.3 & -28.247413 & -52.277758 & E. indica (L.) Gaertn. & 100 \\
\hline & E 4.1 & -28.215843 & -52.464400 & E. indica (L.) Gaertn. & 100 \\
\hline & E 4.2 & -28.215843 & -52.464400 & E. indica (L.) Gaertn. & 100 \\
\hline \multirow{3}{*}{ Carazinho } & E 6.1 & -28.333249 & -52.846361 & E. indica (L.) Gaertn. & 100 \\
\hline & E 6.3 & -28.333249 & -52.846361 & E. tristachya (Lam.) Lam. & 100 \\
\hline & E 6.4 & -28.333249 & -52.846361 & E. indica (L.) Gaertn. & 100 \\
\hline $\mathrm{St}^{\mathrm{a}}$ Bárbara do Sul & E 7.2 & -28.383678 & -53.312778 & E. indica (L.) Gaertn. & 100 \\
\hline \multirow{8}{*}{ Cruz Alta } & E 9.1 & -28.622443 & -53.689638 & E. indica (L.) Gaertn. & 100 \\
\hline & E 9.2 & -28.622443 & -53.689638 & E. indica (L.) Gaertn. & 100 \\
\hline & E 9.3 & -28.622443 & -53.689638 & E. indica (L.) Gaertn. & 100 \\
\hline & E 9.4 & -28.622443 & -53.689638 & E. indica (L.) Gaertn. & 100 \\
\hline & E 9.5 & -28.622443 & -53.689638 & E. indica (L.) Gaertn. & 100 \\
\hline & E 9.6 & -28.622443 & -53.689638 & E. indica (L.) Gaertn. & 100 \\
\hline & E 9.7 & -28.622443 & -53.689638 & E. indica (L.) Gaertn. & 100 \\
\hline & E 9.8 & -28.622443 & -53.689638 & E. indica (L.) Gaertn. & 100 \\
\hline \multirow{3}{*}{ Ijuí } & E 10.1 & -28.447276 & -53.875819 & E. indica (L.) Gaertn. & 99 \\
\hline & E 10.3 & -28.447276 & -53.875819 & E. indica (L.) Gaertn. & 100 \\
\hline & E 10.4 & -28.447276 & -53.875819 & E. indica (L.) Gaertn. & 100 \\
\hline \multirow{9}{*}{ Boa Vista do Incra } & E 11.1 & -28.880085 & -53.472223 & E. indica (L.) Gaertn. & 100 \\
\hline & E 11.2 & -28.880085 & -53.472223 & E. indica (L.) Gaertn. & 100 \\
\hline & E 11.3 & -28.880085 & -53.472223 & E. indica (L.) Gaertn. & 100 \\
\hline & E 11.4 & -28.880085 & -53.472223 & E. indica (L.) Gaertn. & 100 \\
\hline & E 11.5 & -28.880085 & -53.472223 & E. indica (L.) Gaertn. & 100 \\
\hline & E 12.1 & -28.940277 & -53.411684 & E. indica (L.) Gaertn. & 100 \\
\hline & E 12.2 & -28.940277 & -53.411684 & E. indica (L.) Gaertn. & 100 \\
\hline & E 12.3 & -28.940277 & -53.411684 & E. indica (L.) Gaertn. & 97 \\
\hline & E 13.1 & -28.941941 & -53.405295 & E. indica (L.) Gaertn. & 100 \\
\hline \multirow{4}{*}{ Tupanciretã } & E 14.2 & -29.037882 & -53.674288 & E. indica (L.) Gaertn. & 100 \\
\hline & E 14.3 & -29.037882 & -53.674288 & E. indica (L.) Gaertn. & 100 \\
\hline & E 14.4 & -29.037882 & -53.674288 & E. indica (L.) Gaertn. & 100 \\
\hline & E 15.1 & -29.049263 & -53.717768 & E. indica (L.) Gaertn. & 100 \\
\hline $\mathrm{CV}(\%)^{\frac{2}{2}}$ & - & - & - & - & 1.03 \\
\hline
\end{tabular}

$1 /$ ns $=$ non-significant by the F-test at $5 \%$ probability. ${ }^{2 /}$ Coefficient of variation. 

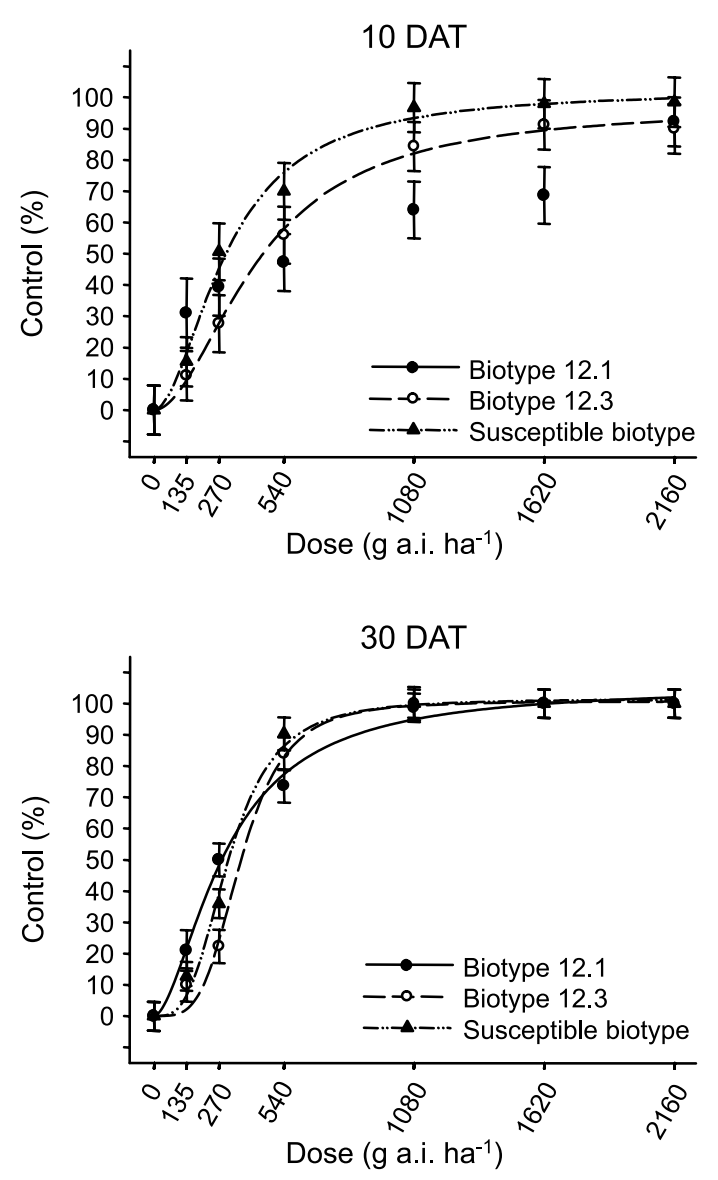
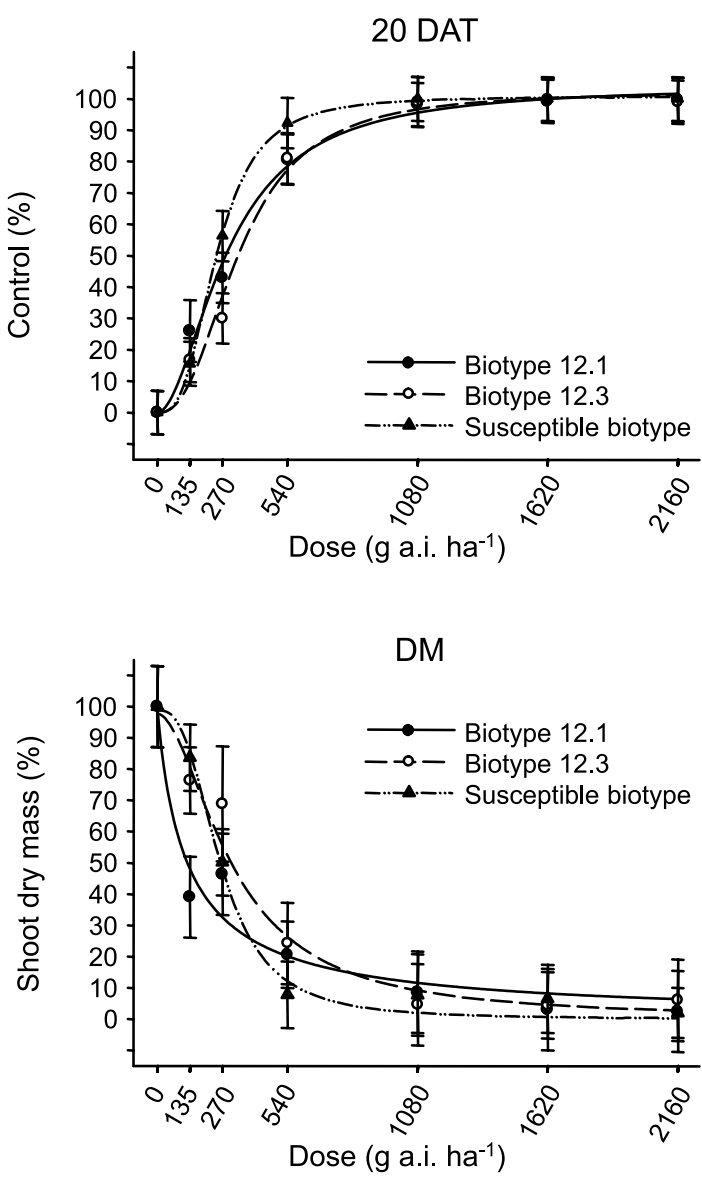

The dots represent the values, and the bars, the confidence intervals of the mean.

Figure 1 - Control (\%) at 10, 20 and 30 days after treatment (DAT) and shoot dry mass (DM) (\%) of the biotypes of Eleusine indica with suspected resistance to glyphosate $12.1(\bullet)$ and 12.3 (o) and susceptible $(\boldsymbol{\Delta})$ by applying different herbicide doses $(0,135$, $270,540,1,080,1,620$ and 2,160 g a.i. ha- $\left.{ }^{-1}\right)$.

of Carazinho. These two species differ mainly as for inflorescence, cycle and origin. The species E. Tristachya is perennial, originally from South America, and the plants have inflorescences consisting of two to four digitate $1-3 \mathrm{~cm}$ long racemes, with five to thirteen 5-9 $\mathrm{mm}$ long spikelets. In contrast, E. indica is annual and originally from Asia and Malaysia; its inflorescence is formed by five to twelve digitate or subdigitate racemes with six to ten spikelets of 5 to $5.5 \mathrm{~mm}$ in length (Agrasar et al., 2005; Boldrini et al. 2005).

The predominance of E. indica can be attributed to the fact that plants of this species are more competitive compared with those of E. tristachya and occur more often in crops (Agrasar et al. 2005; Boldrini et al. 2005). A floristic survey conducted in natural field in the city of Uruguaiana (Rio Grande do Sul) showed the occurrence of E. tristachya only (Galvani et al. 1994).

However, a similar survey conducted in an rice field rotated with soybean, $E$. indica proved to be one of the most frequent species, while the presence of $E$. tristachya was not observed (Erasmo et al. 2004). These data show that plants of $E$. indica found in the soybean crops may also occur in rice fields, thus confirming the widespread occurrence of this species.

For the experiment of dose-response curve, data were fitted to a sigmoidal logistic regression equation for all variables except for control of biotype 12.1 at 10 DAT (Figure 1). 
In general, for doses above $270 \mathrm{~g}$ a.i. $\mathrm{ha}^{-1}$ of glyphosate, less control was observed for the biotypes of Goosegrass suspected of resistance, compared with the notoriously susceptible biotype (Figure 1). However, the control of all biotypes was over $90 \%$ at 20 and 30 DAT at a dose of 1,080 $\mathrm{g}$ a.i. ha ${ }^{-1}$ (Figure 1). In glyphosate-tolerant biotypes of $E$. heterophylla, the dose of $720 \mathrm{~g}$ a.i. ha $^{-1}$ was sufficient to cause plant death (Vargas et al., 2011).

In glyphosate-resistant biotypes of Conyza bonariensis and Lolium multiflorum, the doses of 1,200 and $1,440 \mathrm{~g}$ a.i. ha ${ }^{-1}$, respectively, were not enough to control these plants (Roman et al., 2004; Lamego \& Vidal, 2008). For the biotype of E. indica resistant to the same herbicide, the dose of $840 \mathrm{~g}$ a.i. ha ${ }^{-1}$, recommended for the management of the species, provided less than 50\% control, while near $100 \%$ control was observed at doses above 1,680 g a.i. ha-1 (Mueller et al., 2011). It should be noted that for doses of glyphosate used by most producers in soybean crops in Rio Grande do Sul, ranging between 720 and 1,080 g a.i. ha ${ }^{-1}$ (Ulguim, 2012), control of biotypes was higher than $85 \%$. However, if the occurrence of high infestations is taken into account, which is common for liliopsida species, the control level of $85 \%$ may not be suitable, and it may be the cause of control failures. In this case, by selecting the biotypes with greater tolerance, producers would be leading the population to demand a higher dose of glyphosate year after year in order to obtain satisfactory control.

The data for DM corroborate the results obtained for the control, in which both suspected resistant biotypes, 12.1 and 12.3, had higher DM yield compared to the susceptible biotype at the doses above $540 \mathrm{~g}^{\text {a.i. }} \mathrm{ha}^{-1}$ (Figure 1). At the dose of $1,080 \mathrm{~g}$ a.i. ha ${ }^{-1}$ or above, there was no difference among biotypes, and the values were close to zero, confirming the effectiveness of herbicide control of these doses (Figure 1).

The observation of LD50 values at 5\% probability showed that the LD50 of 12.3 biotype had a significant effect on all evaluation periods, compared with the susceptible population, with higher values than those observed for the latter (Table 2), while biotype $12.1 \mathrm{had}$ a significant effect at 20 and 30 DAT and the value obtained in the last assessment was lower than that found for the LD50 of the susceptible biotype. This result can be attributed to the fact that biotype 12.1, in smaller doses, showed superior control than that of the other biotypes, even though in some cases this response did not show a significant effect (Figure 1). The values found for GR50 showed no difference between biotype 3.12 and the susceptible biotype, and for biotype 12.1, although there was difference compared to the susceptible one, the GR50 of this biotype was less than 1 , like the one obtained for the LD50 at 30 DAT (Table 2).

The results observed in this study were similar to those found in susceptible biotype of E. indica (396 $\pm 235 \mathrm{~g}$ a.i. $\left.\mathrm{ha}^{-1}\right)$ in a study to identify the resistance of this species in Malaysia, where the resistant biotype showed LD50 value around 4,500 g a.i. $\mathrm{ha}^{-1}$ (Lee \& Ngim, 2000). In glyphosate-resistant $L$. rigidum, the LD50 was similar to that observed for biotype 12.3, however, at a dose of $860 \mathrm{~g}$ a.i. ha ${ }^{-1}$, more than $10 \%$ of the plants survived herbicide application (Kaundun et al., 2011). The GR50 values of the glyphosate-resistant biotypes of E. indica were $261 \mathrm{~g}$ a.i. ha ${ }^{-1}$ (Mueller et al., 2011) and $227 \mathrm{~g}$ a.i. ha ${ }^{-1}$ (Kaundun et al., 2008). Thus, the data obtained can be considered similar to those found in other studies related to resistance to glyphosate.

Based on the result obtained from the RF values, it can be inferred that Goosegrass biotype 12.1 is not resistant, as it showed a value lower than 1.0 on the final assessment (Table 2).

For a biotype to be considered resistant, it must survive after exposure to the herbicide and show better performance than the susceptible one, as evidenced by the ratio resistant: susceptible (Gazziero et al., 2009). In contrast, biotype 3.12 can be considered resistant because the RF values were above 1.0 in all evaluation periods (Table 2).

The RF of the glyphosate-resistant biotypes of E. indica ranged between 7.0 and 12.0, based on the $\mathrm{DL}_{50}$ of the biotypes (Lee \& Ngim, 2000; Mueller et al., 2011). However, it is more common to find $\mathrm{RF}$ to glyphosate ranging from 2.0 to 5.0 , depending on the species studied (Kaundun et al., 2008; Lamego \& Vidal, 2008; 
Tabela 2 - Dose required to control $50 \%$ of the population $\left(\mathrm{LD}_{50}\right)$ in order to reduce by $50 \%$ the production of shoot dry mass (GR50), and resistance factor (RF) of biotypes of Eleusine indica with suspected resistance to glyphosate 12.1 and 12.3 and susceptibility in response to the application of different herbicide doses $(0,135,270,540,1,080,1,620$ and 2,160 g a.i. ha $\left.{ }^{-1}\right)$

\begin{tabular}{|c|c|c|c|c|}
\hline Biotype & Equation & $\mathrm{R}^{2}$ & $\begin{array}{l}\mathrm{LD}_{50} \text { or } \mathrm{GR}_{50} \\
\left(\mathrm{~g} \text { a.i. } \mathrm{ha}^{-1}\right)\end{array}$ & $\mathrm{RF}^{1 /}$ \\
\hline \multicolumn{5}{|c|}{$10 \mathrm{DAT}^{2 /}$} \\
\hline 12.1 & - & - & - & - \\
\hline 12.3 & $\mathrm{y}=97.02 /\left[1+(\mathrm{x} / 438.87)^{-1.89}\right]$ & 0.96 & $453(406-500)^{3 /}$ & $1.52 * \frac{4}{\prime}$ \\
\hline Susceptible & $\mathrm{y}=102.28 /\left[1+(\mathrm{x} / 306.11)^{-1.87}\right]$ & 0.97 & $299(276-322)$ & - \\
\hline \multicolumn{5}{|c|}{$20 \mathrm{DAT}$} \\
\hline 12.1 & $y=104.17 /\left[1+(x / 295.05)^{-1.86}\right]$ & 0.97 & $283(259-306)$ & $1.15^{*}$ \\
\hline 12.3 & $y=102.33 /\left[1+(x / 314.19)^{-2.45}\right]$ & 0.97 & $335(313-357)$ & $1.37^{*}$ \\
\hline Susceptible & $y=100.79 /\left[1+(x / 246.42)^{-2.90}\right]$ & 0.99 & $245(237-253)$ & - \\
\hline \multicolumn{5}{|c|}{30 DAT } \\
\hline 12.1 & $\mathrm{y}=105.45 /\left[1+(\mathrm{x} / 298.09)^{-1.71}\right]$ & 0.98 & $281(261-300)$ & $0.91 *$ \\
\hline 12.3 & $y=100.45 /\left[1+(x / 363.35)^{-3.90}\right]$ & 0.99 & $362(350-374)$ & $1.17 *$ \\
\hline Susceptible & $\mathrm{y}=101.46 /\left[1+(\mathrm{x} / 312.31)^{-3.18}\right]$ & 0.99 & $309(301-318)$ & - \\
\hline \multicolumn{5}{|c|}{$\mathrm{DM}^{\frac{5}{}}$} \\
\hline 12.1 & $\mathrm{y}=99.34 /\left[1+(x / 125.79)^{0.94}\right]$ & 0.94 & $124(102-146)^{2}$ & $0.47 *$ \\
\hline 12.3 & $\mathrm{y}=99.61 /\left[1+(x / 314.54)^{1.84}\right]$ & 0.92 & $313(273-353)$ & $1.19^{\mathrm{ns}}$ \\
\hline Susceptible & $y=98.77 /\left[1+(x / 264.54)^{2.76}\right]$ & 0.97 & $262(248-276)$ & - \\
\hline
\end{tabular}

1/ Factor of resistance to glyphosate obtained by dividing the LD50 or GR50 of the biotypes compared to the susceptible population. $2 /$ Days after treatment. ${ }^{3 /}$ Values $\dagger$ in parentheses are for the confidence interval at $95 \%$ average. ${ }^{4 / *}$ or ns indicate nonsignificant difference characterized by presence or absence of overlapping, respectively, of the confidence interval for the LD50 or GR50 of the susceptible population, in relation to the biotype assessed. ${ }^{5 /}$ Shoot dry mass at 30 days after treatment.

Kaundun et al., 2011). Thus, according to the result obtained, the Goosegrass biotype 12.3 can be considered to have low level resistance, considering the low value of the RF at $30 \mathrm{DAT}$ (1.17), and also due to the fact that plant death occurs at the maximum registered dose of the herbicide (Christoffoleti \& López-Ovejero, 2008; Steckel et al., 2008; Gazziero et al., 2009).

Concern over the control failures of $E$. indica is relevant, and the results indicate low-level resistance that can develop into resistance if the management practices of this species are not changed. However, the observed failure to control Goosegrass cannot be attributed only to the occurrence of low-level resistance; there are other factors involved, such as the dose used, the stage of plant growth, factors associated with the technology of application, among others.

It has been argued that the low level of resistance to glyphosate can be overcome by adjusting the dose of the herbicide to higher levels (Owen et al., 2011). However, the use of higher doses may result in an increase in selection pressure and, therefore, the biotypes may develop resistance within a short period of time. Thus, it is recommended that producers use control alternatives with alternative herbicides in order to mitigate the evolution of resistance of Goosegrass to glyphosate. Another efficient way could be the use of other crops that re resistant to other herbicides, thus combining crop rotation and herbicide mode of action.

The results of this study showed that the dose of 2,160 a.i. ha ${ }^{-1}$ of glyphosate effectively controlled all the biotypes of Goosegrass, especially for $E$. indica, collected with suspected resistance to glyphosate in Rio Grande do Sul at the stage of four leaves per tiller. Biotype 12.3 showed low level resistance to glyphosate, which may contribute to the observed control failures in soybean crops in Rio Grande do Sul. 


\section{LITERATURE CITED}

AGROFIT. Disponível em: <www.agricultura.gov.br> Acesso em: 30 set. 2010.

AGRASAR, Z. E. R. de et al. Manual ilustrado de las gramíneas dela província de La Pampa. La Pampa, Santa Rosa: Universidade Nacional de La Pampa, 2005. 374 p.

AVILA, L. A. et al. Assessment of acetolactate synthase (ALS) tolerance to imazethapyr in red rice ecotypes (Oryza spp.) and imidazolinone tolerant/resistant rice (Oryza sativa) varieties. Pest Manag. Sci., v. 61, n. 2, p. 171-178, 2005.

BOLDRINI, I. I. et al. Morfologia e taxonomia de gramíneas sul-riograndenses. Porto Alegre: Universidade Federal do Rio Grande do Sul, 2005. 96 p.

CHRISTOFFOLETI, P. J.; LÓPEZ-OVEJERO, R. F. Resistência das plantas daninhas a herbicidas: definições, bases e situação no Brasil e no mundo. In: CHRISTOFFOLETI, P.J. (Ed.). Aspectos de resistência de plantas daninhas a herbicidas. 3.ed. Piracicaba: HRAC-BR, 2008. p. 9-53.

COMISSÃO DE QUÍMICA E FERTILIDADE DO SOLO CQFSRS/SC. Manual de adubação e calagem para os estados do Rio Grande do Sul e Santa Catarina. 10.ed. Porto Alegre: Sociedade Brasileira de Ciência do Solo/Núcleo Regional Sul, 2004. 400 p.

DAL MAGRO, T. et al. Supressão da dormência de sementes de capim pé de galinha (Eleusine indica). In: CONGRESSO BRASILEIRO DA CIÊNCIA DAS PLANTAS DANINHAS, 27., 2010, Ribeirão Preto. Anais... Ribeirão Preto: Funep, 2010. p. $1177-1181$

ERASMO, E. A. L. et al. Levantamento fitossociológico das comunidades de plantas infestantes em áreas de produção de arroz irrigado cultivado sob diferentes sistemas de manejo.

Planta Daninha, v. 22, n. 2, p. 195-201, 2004.

FONTANA, L. C. Identificação de espécies, suscetibilidade a herbicidas e habilidade competitiva de milhã (Digitaria spp.) no Estado do Rio Grande do Sul. 2011. 125 f. Tese (Doutorado em Fitossanidade) Universidade Federal de Pelotas, Pelotas, 2011.

FRANS, R. et al. Experimental design and techniques for measuring and analyzing plant responses to weed control practices. In: CAMPER, N.D. (Ed.) Research methods in weed science. 3.ed. Champaign: Southern Weed Science Society, 1986. $37 \mathrm{p}$.

GALVANI, F. R. et al. Levantamento da flora de campo nativo no município de Uruguaiana. R. Fac. Zootec. Veter. Agron., v. 1, n. 1, p. 15-23, 1994.
GAZZIERO, D. L. P. et al. Critérios para relatos oficiais estatísticos de biótipos de plantas daninhas resistentes a herbicidas. In: AGOSTINETTO, D; VARGAS, L. (Eds.). Resistência de plantas daninhas a herbicidas no Brasil. Passo Fundo: Berthier, 2009. p. 91-101.

HALL, L. M. et al. Resistance to acetolactate synthase inhibitors and quinclorac in a biotype of false clover (Gallium spurium). Weed Sci., v. 46, n. 1, p. 390-396, 1998.

HEAP, I. Criteria for confirmation of herbicide-resistant weeds - with specific emphasis on confirming low level resistance. Disponível em: $<\mathrm{http}$ ://www.weedscience.org $>$. Acesso em: 19 ago. 2010

HEAP, I. Internacional survey of herbicide resistant weeds. Disponível em: <www.weedscience.org $>$. Acesso em: 20 mar. 2012

\section{INSTITUTO BRASILEIRO DE GEOGRAFIA E} ESTATÍSTICA - IBGE. Levantamento sistemático da produção agrícola. Disponível em: <http://www.ibge.gov.br/ home/estatistica/ indicadores/agropecuaria/lspa/ 1spa_201111.pdf > . Acesso em: 19 jan. 2008.

KAUNDUN, S. S. et al. Importance of the P106S target-site mutation in conferring resistance to glyphosate in a goosegrass (Eleusine indica) population from the Philippines. Weed Sci., v. 56, n. 5, p. 637-646, 2008.

KAUNDUN, S. S. et al. A novel P106L mutation in EPSPS and an unknown mechanism(s) act additively to confer resistance to glyphosate in a South African Lolium rigidum population. J. Agric. Food Chem., v. 59, n. 7, p. 3227-3233, 2011.

KISSMANN, K. G. Plantas infestantes e nocivas. 3.ed. São Paulo: Basf Brasileira, 2007. Tomo I. CD ROM.

LAMEGO, F. P.; VIDAL, R. A. Resistência ao glyphosate em biótipos de Conyza bonariensis e Conyza canadensis no Estado do Rio Grande do Sul, Brasil. Planta Daninha, v. 26, n. 2, p. 467-471, 2008.

LEE, L. J.; NGIM, J. A first report of glyphosate-resistant goosegrass (Eleusine indica (L) Gaertn) in Malaysia. Pest Manag. Sci., v. 56, n. 4, p. 336-339, 2000.

MUELLER, T. C. et al. Glyphosate-resistant goosegrass (Eleusine indica) confirmed in Tennessee. Weed Sci., v. 59, n. 4, p. 562-566, 2011.

OWEN, M. D. K. et al. Benchmark study on glyphosateresistant crop systems in the United States. Part 2: Perspectives. Pest Manag. Sci., v. 67, n. 7, p. 747-757, 2011.

Planta Daninha, Viçosa-MG, v. 31, n. 3, p. 677-686, 2013 
ROMAN, E. S. et al. Resistência de azevém (Lolium

multiflorum) ao herbicida glyphosate. PlantaDaninha, v. 22, n. 2, p. 301-306, 2004.

SIGMAPLOT - Scientific Graphing Software. Version $10.0,2007$.

STECKEL, L. E. et al. Palmer amaranth (Amaranthus palmeri) in Tennessee has low level glyphosate resistance. Weed Technol., v. 22, n. 1, p. 119-123, 2008
ULGUIM, A. R. Resposta de capim pé-de-galinha (Eleusine spp.) ao herbicida glyphosate. 2012. $71 \mathrm{f}$. Dissertação (Mestrado em Fitossanidade) - Universidade Federal de Pelotas, Pelotas, 2012

VARGAS, L. et al. Resposta de biótipos de Euphorbia heterophylla a doses de glyphosate. Planta Daninha, v. 29, p. 1121-1128, 2011. (Número Especial) 